\title{
Prophylaxis against systemic infection after transrectal biopsy for suspected prostatic carcinoma
}

\author{
E C ASHBY， M REES，C H DOWDING
}

British Medical fournal, 1978, 2, 1263-1264

had co-trimoxazole two tablets twice daily substituted for ampicillin. After a further period of 24-48 hours-that is, three or four days after biopsy - a second blood sample was taken.

Methods used for the collection and culture of blood were as Summary and conclusions

Five minutes after transrectal prostatic biopsy 16 out of 21 patients were shown by blood culture to have bacteraemia. Antibiotic prophylaxis-routinely with ampicillin and metronidazole for 48 hours-prevented progression to septicaemia, and four days after the procedure all blood samples were negative.

Irrespective of whether antibiotic prophylaxis is used, blood culture should be routine in all patients undergoing transrectal prostatic biopsy.

\section{Introduction}

Transrectal prostatic biopsy with Trucut needles is now an established method of diagnosing prostatic carcinoma. Palpation is unreliable, ${ }^{1}$ and histological proof is advisable before treatment. As prostatic carcinoma tends to develop in the periphery of the gland near the capsule in the posterior part of the lateral lobes," transrectal or transperineal puncture may be preferable to resectoscope biopsy in early cases. Transrectal biopsy is easily performed in the outpatient department, requires no anaesthetic, and provides a good specimen for the pathologist. Schulman reported a single case of mild urethral damage as the only complication in 50 cases. $^{3}$

In the year before the present study three out of 23 patients undergoing transrectal biopsy under the care of one surgeon developed features of septicaemia. All recovered with treatment. Blood cultures in two cases (the third patient received antibiotics at home) grew a clostridium or a coliform.

We thought that prophylactic antibiotics should be used after transrectal prostatic biopsy to reduce the problems arising from systemic and local infections. A study was designed $(a)$ to assess the incidence of bacteraemia after the procedure and (b) to evaluate the efficacy of the chosen prophylaxis-namely, ampicillin and metronidazole. These antibiotics may be taken by mouth, have relatively few side effects, and are effective against a fairly broad spectrum of organisms, including the anaerobes prevalent in the large bowel.

\section{Patients and methods}

During six months 21 patients under the care of three surgeons underwent transrectal prostatic biopsy for suspected malignancy noted on digital palpation. Two separate specimens were taken from each gland with Trucut needles, as described. ${ }^{3}$ Blood for culture was withdrawn five minutes later, then an eight-hourly combination of ampicillin $500 \mathrm{mg}$ and metronidazole $400 \mathrm{mg}$ was prescribed to be taken by mouth for 48 hours. One patient allergic to penicillin

St Richard's Hospital, Chichester, West Sussex PO19 4SE

E C ASHBY, MCHIR, FRCS, consultant surgeon

$M$ REES, FRCS, surgical registrar

C H DOWDING, FIMLs, chief medical laboratory scientific officer in microbiology follows. After venepuncture with strict antiseptic techniques two $5 \mathrm{ml}$ samples of blood were put into digest and thiol broth respectively and immediately incubated at $37^{\circ} \mathrm{C}$. Aerobic and anaerobic subcultures were made at $1,2,7$, and 14 days. For selection of anaerobes a gentamicin blood agar was used. Sensitivity to antibiotics was determined by the disc-diffusion method.

\section{Results and comment}

Of the 21 blood samples taken five minutes after biopsy, $16(76 \%)$ were positive on culture: nine grew one bacterial species, six two, and one three (see table). All organisms were sensitive to either ampi-

Organisms isolated in 16 positive blood cultures from 21 patients

\begin{tabular}{|c|c|c|c|}
\hline $\begin{array}{l}\text { Aerobic organisms }(n=10) \text { : } \\
\text { Aerobic, non-haemolytic }\end{array}$ & No & $\begin{array}{c}\text { Anaerobic organisms }(\mathrm{n}=14) \text { : } \\
\text { Bacteroides spp } . .\end{array}$ & $\begin{array}{r}\text { No } \\
\ldots \quad 11\end{array}$ \\
\hline $\begin{array}{rll}\text { streptococci }_{\text {Escherichia coli }} & \ldots & \ldots \\
\text { E } & \ldots\end{array}$ & $\begin{array}{l}\cdots \\
.\end{array}$ & $\begin{array}{c}\text { Anaerobic, non-haemolytic } \\
\text { streptococci }\end{array}$ & .. 3 \\
\hline Enterococci $\quad \ldots$ & . & & \\
\hline
\end{tabular}

cillin or metronidazole except for two coliforms; neither of the two patients concerned had clinical symptoms, though one had a persistent growth of the same organism in a midstream specimen of urine, which responded to co-trimoxazole. Three other patients had significant growth of organisms in their midstream specinens of urine after biopsy. Four patients had rigors, malaise, and flushes, which resolved in one to five days. None of the blood samples taken after antibiotic prophylaxis grew any organisms. In 12 of the 21 cases $(57 \%)$ biopsy confirmed a carcinoma, which is in keeping with the incidence in other series. ${ }^{1}$ In our small series there was no apparent difference in the incidence of bacteraemia between those with and those without carcinoma.

Sensitivities were studied to see whether a different combination of orally administered and relatively non-toxic antibiotics would have offered any advantage over the chosen prophylaxis. All anaerobic organisms were sensitive to metronidazole. Of the aerobic organisms, the two enterococci were resistant to co-trimoxazole but sensitive to ampicillin, and two coliforms resistant to ampicillin were sensitive to co-trimoxazole. Thus there was little to choose between ampicillin and co-trimoxazole for prophylaxis against the aerobic organisms, while metronidazole appeared to be the drug of choice for anaerobes.

\section{Discussion}

Several workers have noted fever and chills after prostatic biopsy, though none have provided confirmatory cultural proof of bacteraemia. ${ }^{4}{ }^{5}$ Harris et $a l^{6}$ described two cases of anaerobic septicaemia after transrectal prostatic biopsy that occurred despite prophylaxis with gentamicin. One patient died from fulminating clostridial septicaemia, while the other underwent laparotomy to drain a suprapubic abscess after bacteroides septicaemia. They concluded that there is a need to cover patients against anaerobic organisms after transrectal biopsy. Our results show that metronidazole together with either ampicillin or co-trimoxazole is a satisfactory combination and suggest that 48 hours of treatment is adequate. Whether or not antibiotics are given, samples for blood culture should be taken 
immediately after prostatic biopsy in case an unusual organism gets into the blood stream. By the time illness is apparent sensitivities might be available. Also the urine should be cultured about one week after the procedure to exclude persistent urinary tract infection.

We are engaged in a further trial using the same antibiotic cover but with preliminary cleansing of the bowel with a phosphate enema followed by an aqueous solution of povidoneiodine applied through a proctoscope. To date none of the blood samples taken five minutes after biopsy have been positive (six patients), and time may tell whether it is sufficient to use just this local prophylaxis.

We thank Professor C H Lack for helpful advice, Dr B Subagjo for help in the laboratory, Mr R P M Miles and Mr W F P Gammie for allowing us to study their patients, and the Chichester Ladies' Circle for financial support.

\section{References}

${ }^{1}$ Emmett, J L, Barber, K W, and Jackman, R J, fournal of Urology, 1962 $87,460$.

${ }^{2}$ Franks, L M, Annals of the Royal College of Surgeons of England, 1954, 14, 92.

3 Schulman, C C, International Urology and Nephrology, 1970, 2, 157

4 Barnes, R W, and Niran, C A, fournal of Urology, 1972, 108, 897.

${ }^{5}$ Dowlen, L W, Black, N L, and Polmano, C A, South African Medical Fournal, 1974, 67, 1453.

${ }^{6}$ Harris, L F, et al, Archives of Internal Medicine, 1978, 138, 393.

(Accepted 29 September 1978)

\section{SHORT REPORTS}

\section{Unusual chlamydial infection in a human renal allograft recipient}

Immunocompromised patients commonly experience repeated infections due to a wide spectrum of opportunist organisms. ${ }^{1} \mathrm{We}$ report here an infection with a chlamydial agent that produced a nearfatal illness in a renal transplant recipient.

\section{Case report}

A 38-year-old housewife received a cadaveric renal transplant in October 1975. Graft function remained excellent and no rejection episodes occurred. Her only problems since transplant had been tertiary hyperparathyroidism recurrent bacteriuria, and a chronic ringworm infection caused by Microsporum canis contracted from her family of cats. She was admitted on 11 November 1977 with a 10-day history of malaise and lethargy. She was pyrexial and the spleen tip was palpable, but examination otherwise showed nothing abnormal. During the next two weeks her condition deteriorated steadily. She became hyperpyrexial and developed hepatosplenomegaly and an unproductive cough. Liver enzyme concentrations rose shortly after admission. The serum aspartate transaminase (serum AST; SGOT) concentration reached a peak of $103 \mathrm{IU} / 1$ on 17 November, and the creatinine clearance fell from a preadmission $70 \mathrm{ml} / \mathrm{min}$ to $21 \mathrm{ml} / \mathrm{min}$ on 21 November. Azathioprine was discontinued on 11 November because of leucopenia. Al bacteriological investigations gave negative results. Acid-fast bacilli were not found in gastric washings and chest radiographs remained normal. Serial titres of complement-fixing antibodies against multiple microbiological agents were stable. The Paul-Bunnell and hepatitis B surface antigen tests gave negative results. Bone marrow trephine and liver biopsy sections both contained foci of necrosis with inflammatory cell infiltration. A provisiona diagnosis of disseminated tuberculous infection was made. On 16 November she was started on rifampicin $600 \mathrm{mg}$ and isoniazid $300 \mathrm{mg}$ daily, corticosteroids were stopped, and normal human immunoglobulin was given. By 21 November she was semicomatose and profoundly ill. Because of rising liver enzyme concentrations rifampicin was discontinued and streptomycin substituted. After her condition had further deteriorated corticosteroids were reintroduced on 24 November. The next day she began gradually to recover.

The results of chlamydial serology are shown in the table. Serum taken on 16 November was fractionated by Sephadex G-200, and $52 \%$ of the complement-fixing activity resided in the $\operatorname{IgM}$ fraction. Subsequently the titre of complement-fixing antibodies rose while that of specific IgM antibodies declined. Clearly the patient had had a primary infection with a chlamydial agent, but we were reluctant to diagnose psittacosis without evidence of lung infection. Furthermore, her only contact with birds had been at her local pet shop, and these birds showed no evidence of psittacosis Serum samples were therefore examined by the microimmunofluorescence technique $^{2}$ for antibodies against a variety of subgroup A ( $C$ trachomatis) and subgroup B ( $C$ psittaci) chlamydial agents. Among the significant rises in antibody titres the most striking was against isolate 457-F, a feline keratoconjunctivitis agent of subgroup $B$ that can cause feline pneumonitis. This was the only Chlamydia against which high-titre specific IgM was detected in the patient's sera. Her three cats were venesected in February 1978, but none had antibodies against the feline keratoconjunctivitis agent. Serum from one ("Sooty"), however, showed an immunofluorescence titre of 128 against a subgroup A serotype. This cat had been ill with a cough at the end of October 1977 .

\section{Comment}

The patient's most striking antibody rise was against the feline keratoconjunctivitis agent, but this Chlamydia has been associated only with conjunctivitis in humans. ${ }^{3}$ Nevertheless, possibly the patient's

Results of serological tests for Chlamydia antigens

\begin{tabular}{|c|c|c|c|c|c|c|c|c|c|}
\hline \multirow{3}{*}{\multicolumn{2}{|c|}{$\begin{array}{l}\text { Tests and chlamydial } \\
\text { antigens used }\end{array}$}} & \multicolumn{8}{|c|}{ Antibody titres $(\% \mathrm{IgM})$ of sera taken on dates shown } \\
\hline & & \multicolumn{5}{|c|}{ Patient's sera } & \multicolumn{3}{|c|}{ Cats' sera $(1 / 2 / 78)$} \\
\hline & & $8 / 11 / 77$ & $16 / 11 / 77$ & $1 / 12 / 77$ & 19/12/77 & $30 / 1 / 78$ & "Lucky" & "Tina" & "Sooty" \\
\hline $\begin{array}{l}\text { Complement fixation: } \\
\text { Psittacosis/LGV... } \\
\text { Microimmunofluorescence: } \\
\text { Subgroup A strains }\end{array}$ & .. & $<8$ & $32(52)$ & $1024(17)$ & $256(8)$ & $128(*)$ & ND & ND & ND \\
\hline 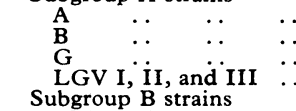 & $\begin{array}{l}\because \\
\because \\
\because\end{array}$ & $\begin{array}{l}<8 \\
<8 \\
<8 \\
<8\end{array}$ & $\begin{array}{l}<8 \\
8(0) \\
16(0) \\
<8\end{array}$ & $\begin{array}{l}128(0) \\
128(0) \\
512(0) \\
\text { ND }\end{array}$ & $\begin{array}{l}\text { ND } \\
\text { ND } \\
\text { ND }\end{array}$ & $\begin{array}{l}<8 \\
<8 \\
16(0) \\
<8\end{array}$ & $\begin{array}{l}<8 \\
<8 \\
<8 \\
<8\end{array}$ & $\begin{array}{l}<8 \\
<8 \\
<8 \\
<8\end{array}$ & $\begin{array}{l}<8 \\
128 \\
<8 \\
<8\end{array}$ \\
\hline 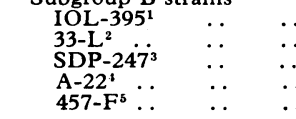 & $\begin{array}{l}. \\
\ldots \\
\cdots \\
\ldots\end{array}$ & $\begin{array}{l}<8 \\
<8 \\
<8 \\
<8\end{array}$ & $\begin{array}{l}<8 \\
<8 \\
32(0) \\
<8 \\
64(25)\end{array}$ & $\begin{aligned} 128(0) \\
64(0) \\
1024(0) \\
128(0) \\
4096(0)\end{aligned}$ & $\begin{array}{l}\text { ND } \\
\text { ND } \\
\text { ND } \\
\text { ND }\end{array}$ & $\begin{array}{r}<8(0) \\
<8(0) \\
32(0) \\
8(0) \\
512(0)\end{array}$ & $\begin{array}{l}<8 \\
<8 \\
<8 \\
<8 \\
<8\end{array}$ & $\begin{array}{l}<8 \\
<8 \\
<8 \\
<8 \\
<8\end{array}$ & $\begin{array}{l}<8 \\
<8 \\
<8 \\
<8 \\
<8\end{array}$ \\
\hline
\end{tabular}

$\mathrm{ND}=$ Not done

*IgM fraction anticomplementary.

$1=$ Human $C$ psittaci strain. $\stackrel{2}{=}=$ Human $C$ psittaci strain. $\quad{ }^{3}=$ Pigeon $C$ psittaci strain. $\quad{ }^{4}=$ Enzootic abortion agent of ewes. ${ }^{5}=$ Cat keratoconjuctivitis agent (feline pneumonitis). 